Article

\title{
Core-Shell Magnetic Gold Nanoparticles for Magnetic Field-Enhanced Radio-Photothermal Therapy in Cervical Cancer
}

\author{
Rui Hu ${ }^{1,2,3}$, Minxue Zheng ${ }^{1}$, Jinchang $\mathrm{Wu}^{3}$, Cheng $\mathrm{Li}^{3}$, Danqing Shen ${ }^{3}$, Dian Yang ${ }^{1,2}, \mathrm{Li} \mathrm{Li}^{1}$, \\ Mingfeng Ge ${ }^{1}$, Zhimin Chang ${ }^{1, *}$ and Wenfei Dong ${ }^{1, *}$ \\ 1 CAS Key Laboratory of Bio-Medical Diagnostics, Suzhou Institute of Biomedical Engineering and Technology, \\ Chinese Academy of Sciences, No. 88 Keling Road, Suzhou 215163, China; huuno@sohu.com (R.H.); \\ minxue.zheng@sibet.ac.cn (M.Z.); 15251855931@163.com (D.Y.); \\ jlu_li@163.com (L.L.); gemf@sibet.ac.cn (M.G.) \\ 2 University of Chinese Academy of Sciences, Beijing 100049, China \\ 3 Department of Radiation Oncology, Affiliated Suzhou Hospital of Nanjing Medical University, \\ Suzhou Municipal Hospital, No. 26 Daoqian RD, Suzhou 215000, China; wjinchang@sina.com (J.W.); \\ chengli1981116@163.com (C.L.); tuzi.go@163.com (D.S.) \\ * Correspondence: changzm@sibet.ac.cn (Z.C.); wenfeidong@sibet.ac.cn (W.D.); Tel.: +86-512-6958-8307 (Z.C.) \\ Academic Editor: Yurii Gun'ko \\ Received: 31 March 2017; Accepted: 8 May 2017; Published: 11 May 2017
}

\begin{abstract}
The combination of radiotherapy (RT) and photothermal therapy (PTT) has been considered an attractive strategy in cervical cancer treatment. However, it remains a challenge to simultaneously enhance the radio-sensitivity of tumor tissue, develop tumor tissue-focused radiation therapies and combine dual therapeutic modalities. In this study, core-shell type magnetic gold $\left(\mathrm{Fe}_{3} \mathrm{O}_{4} @ \mathrm{Au}\right)$ nanoparticles are exploited to achieve the synergistic efficacy of radio-photothermal therapy in cervical cancer. $\mathrm{Fe}_{3} \mathrm{O}_{4} @ \mathrm{Au}$ nanoparticles (NPs) with uniform morphology exhibited superior surface plasmon resonance properties, excellent superparamagnetic properties, good biocompatibility and high photothermal conversion efficiency. For the in vitro tests, a low concentration of $\mathrm{Fe}_{3} \mathrm{O}_{4} @ \mathrm{Au}$ NPs after a short period of near-infrared irradiation lead to the time-dependent death of cervical cancer cells. Further, the combination of RT and PTT induced synergistic anti-cancer effects in vitro. More importantly, an external magnetic field could significantly enhance the synergistic efficacy of $\mathrm{Fe}_{3} \mathrm{O}_{4} @ \mathrm{Au}$ NPs by improving their internalization. Hence, the reported $\mathrm{Fe}_{3} \mathrm{O}_{4} @ \mathrm{Au}$ NPs have the potential to be good nanoagents with excellent magnetic targeting ability for cervical cancer radio-photothermal treatment.
\end{abstract}

Keywords: cervical cancer; magnetic gold nanoparticles; synergetic; radio-photothermal therapy; magnetic field

\section{Introduction}

Cervical cancer is the third most common cancer occurring in women all over the world, with approximately 500,000 new cases and approximately 300,000 deaths each year [1-3]. The clinical treatment procedures for cervical cancer include chemotherapy, radiation therapy, intracavitary or interstitial brachytherapy and even radical hysterectomy [4-6]. The patients' different conditions, such as age, stage of the cancer, and tumor type, determine the different clinical therapeutic schemes [7-9]. Among them, radiotherapy is a prominent tool for many cervical cancer patients, including advanced stage cervical cancer patients and some earlier stage patients not suitable for surgery $[10,11]$. Although radiotherapy has been a major treatment in cervical cancer therapy, poor therapeutic effect and serious radiation-associated side effects such as cardiac toxicity, secondary malignancy, radiation pneumonitis, 
and lymphedema limit its clinical applications [12,13]. When ionizing radiation is applied to the tumor during radiotherapy, very little ionizing radiation energy is absorbed by the tumor tissue, while the normal tissues through which the irradiation beam passes are non-selectively damaged [14]. Therefore, it is urgent to enhance the sensitivity of tumor tissue to radiotherapy and achieve tumor cell-targeted radiotherapy in order to minimize the radiation dose delivered to surrounding healthy tissues, and to combine this approach with other safe treatment modalities to improve the therapeutic efficacy of treating cervical cancer. Currently, near-infrared (NIR) laser-induced photothermal therapy (PTT) has gained great interest due to its favorable biosafety [15]. PTT usually uses photo-absorbing agents to produce localized hyperpyrexia to ablate tumors with minimal invasiveness [16]. In addition, PTT is capable of potentiating radiotherapy via influencing the tumor microenvironment, increasing blood perfusion in tumors and reducing the hypoxic region and the subsequent radiation therapy-induced vascular disruption [17-19]. Hence, the synergistic treatment of radiotherapy and PTT is becoming an attractive approach for cervical cancer treatment. However, it is a challenge to seek an appropriate agent to synchronously improve the kill effect of two therapeutic modalities and enable targeting of the tumor to minimize the damage to normal tissue.

With the fusion of biotechnology and nanotechnology, various nanomaterials have shown promising applications in cancer treatment [20-22]. Among them, gold nanoparticles have achieved great attention owing to their special properties, including versatile surface chemistry, good biocompatible and unique optical properties [23-25]. Gold nanoparticles are not only potential photothermal conversion agents for cancer photothermal therapy through surface plasma resonance processes, but they are also novel radiosensitizers due to their heightened photoelectric absorption efficacy and the improved electrons present [16,26]. Furthermore, gold nanoparticles of the appropriate size tend to localize at the tumor site via the enhanced permeability and retention (EPR) effect, a common nanoparticle delivery mechanism [27]. Passive tumor accumulation has been demonstrated to be facilitated by various target technologies [28,29]. In addition to passive targeting, magnetic targeting is among the most promising targeting technologies in the clinical treatment of tumors [30]. It is well known that a magnetic field can enhance the cellular uptake of nanoparticles containing magnetic materials [31,32]. Moreover, compared with other targeting technologies, a magnetic targeting strategy could be more suitable for clinical application because it is not only a more convenient way to improve agent accumulation at the tumor tissue, but it is also safer because the external stimulus strategy need not change the specific physical or chemical properties of the interior environment [33,34]. Hence, gold nanoparticles combined with magnetic material enable accumulation at a target region using a magnetic field for effective localized therapy at tumor sites, and would be advantageous agents for cervical cancer treatment. Among them, gold-coated magnetic nanoparticles are the most attractive nanoplatforms because the core-shell structure provides improved stabilization, good biocompatibility and surface reactivity. [35]. Many scientists have reported the fabrication of gold-coated magnetic nanoparticles and the application of these nanoparticles to detection, biomolecule immobilization, bio-separation and immunosensors [36-39]. However, there have been few studies on core-shell magnetic gold nanoparticles as radiosensitizers, and the potential of these nanoparticles in cervical cancer treatment has not been developed.

Herein, we designed core-shell magnetic gold $\left(\mathrm{Fe}_{3} \mathrm{O}_{4} @ \mathrm{Au}\right)$ nanoparticles as both photothermal conversion materials and radiosensitizers. $\mathrm{Fe}_{3} \mathrm{O}_{4} @ \mathrm{Au}$ nanoparticles (NPs) with uniform morphology showed a strong magnetic property and superior photothermal effect. Then, we studied the cytotoxicity and endocytosis of $\mathrm{Fe}_{3} \mathrm{O}_{4} @ \mathrm{Au}$ NPs to cancer cells with or without a magnetic field. Finally, the efficacy of photothermal therapy, radiotherapy and synergetic photothermal-radiotherapy were evaluated in vitro. Our results established that $\mathrm{Fe}_{3} \mathrm{O}_{4} @ \mathrm{Au}$ NPs are a promising platform for combined radio-photothermal therapy in cervical cancer. 


\section{Results and Discussion}

\subsection{Synthesis and Characterization}

$\mathrm{Fe}_{3} \mathrm{O}_{4} @ \mathrm{Au}$ NPs were prepared by a single hydrothermal method. Briefly, $\mathrm{Fe}_{3} \mathrm{O}_{4}$ particles were dispersed in $\mathrm{HAuCl}_{4} \cdot 4 \mathrm{H}_{2} \mathrm{O}$ solution by stirring to allow the adsorption of $\mathrm{Au}^{3+}$ onto the $\mathrm{Fe}_{3} \mathrm{O}_{4}$ surface. Then, $\mathrm{NH}_{2} \mathrm{OH}$ solution was added to reduce the $\mathrm{Au}^{3+}$, and core/ shell $\mathrm{Fe}_{3} \mathrm{O}_{4} @ \mathrm{Au}$ NPs were formed. As illustrated in Figure 1a, the TEM images of $\mathrm{Fe}_{3} \mathrm{O}_{4} @ \mathrm{Au}$ NPs show uniform morphology and good dispersity. The $\mathrm{Fe}_{3} \mathrm{O}_{4}$ core was surrounded by a layer of gold shell with a thickness of $\sim 20 \mathrm{~nm}$, and the mean diameter of the produced $\mathrm{Fe}_{3} \mathrm{O}_{4} @ \mathrm{Au}$ NPs was $100 \mathrm{~nm}$ by dynamic light scattering analysis (Figure 1b). The energy dispersive X-ray spectrum further demonstrated that the core/shell nanoparticles contained iron and oxygen, as shown in Figure 1c. Then, we detected the Zeta potential of $\mathrm{Fe}_{3} \mathrm{O}_{4} \mathrm{NPs}$ and core-shell $\mathrm{Fe}_{3} \mathrm{O}_{4} @ \mathrm{Au}$ NPs. As shown in Figure $1 \mathrm{~d}, \mathrm{Fe}_{3} \mathrm{O}_{4} \mathrm{NPs}_{\text {sere }}$ negative and core-shell Fe3O4@Au NPs were positive after gold coating. Encouraged by the hybrid structure, we further explored the magnetic and optical properties of $\mathrm{Fe}_{3} \mathrm{O}_{4} @ \mathrm{Au} \mathrm{NPs}$. As shown in Figure 1e, $\mathrm{Fe}_{3} \mathrm{O}_{4} @ \mathrm{Au}$ NPs possess a superb magnetic response in aqueous solution with a saturation magnetization of approximately $30 \mathrm{emu} / \mathrm{g}$, suggesting that the NPs enabled attraction in response to the extra magnetic field. The optical spectrum of the NPs is shown in Figure 1f. Pure $\mathrm{Fe}_{3} \mathrm{O}_{4}$ nanospheres exhibited very weak absorption in the visible-near infrared (NIR) spectrum. Notably, $\mathrm{Fe}_{3} \mathrm{O}_{4} @ \mathrm{Au}$ NPs showed strong visible absorption at $\sim 590 \mathrm{~nm}$ and significantly improved the NIR absorption at $808 \mathrm{~nm}$. To explore the photoabsorption capability of $\mathrm{Fe}_{3} \mathrm{O}_{4} @ \mathrm{Au}$ NPs at $808 \mathrm{~nm}$, we calculated the extinction coefficient of $\mathrm{Fe}_{3} \mathrm{O}_{4} @ \mathrm{Au}$ NPs according to the following equation [40]:

$$
\varepsilon=\mathrm{A} / \mathrm{LC}=\left(\mathrm{AV}_{\mathrm{NC}} \rho \mathrm{N}_{\mathrm{A}}\right) /\left(\mathrm{LC}_{\mathrm{wt}}\right)
$$

In this equation, $\mathrm{A}$ is the absorbance at $808 \mathrm{~nm}, \mathrm{~L}$ represents the path-length $(1 \mathrm{~cm})$, and $\mathrm{C}$ represents the molar concentration of $\mathrm{Fe}_{3} \mathrm{O}_{4} @ \mathrm{Au} \mathrm{NPs}$. The molar concentration $\mathrm{C}$ can be calculated by $\mathrm{C}=\mathrm{C}_{\mathrm{wt}} / \mathrm{V}_{\mathrm{NC}} \rho \mathrm{N}_{\mathrm{A}} \cdot \mathrm{C}_{\mathrm{wt}}$ is the weight concentration. $\mathrm{N}_{\mathrm{A}}$ is Avogadro's constant. $\mathrm{V}_{\mathrm{NC}}$ and $\rho$ respectively represent the average volume and density of the $\mathrm{Fe}_{3} \mathrm{O}_{4}$-Au NPs. The calculated extinction coefficient $\varepsilon$ was approximately $1.26 \times 10^{11}$. The high extinction coefficient at $808 \mathrm{~nm}$ indicated that NIR light could induce a thermal effect in $\mathrm{Fe}_{3} \mathrm{O}_{4} @ \mathrm{Au}$ NPs.

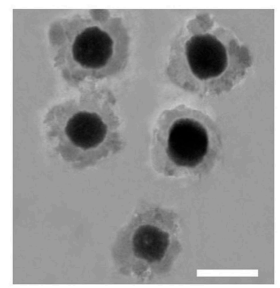

d

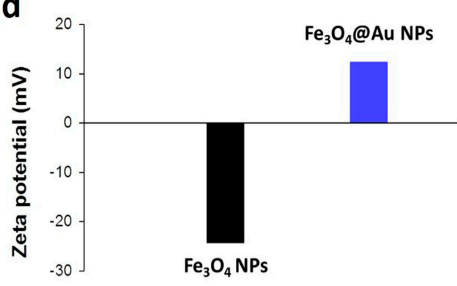

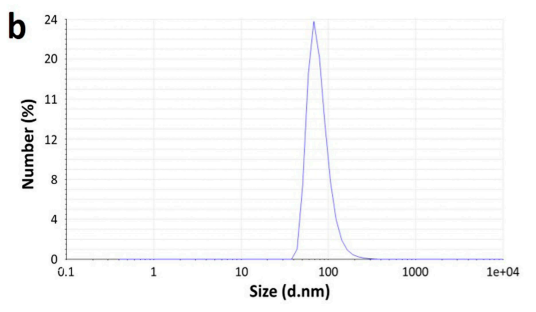
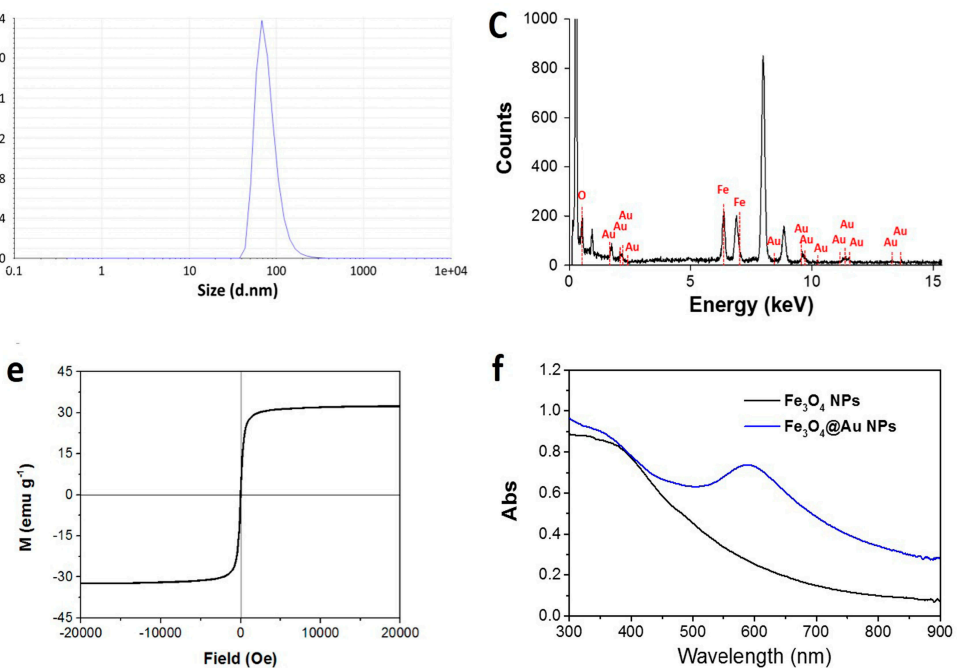

f

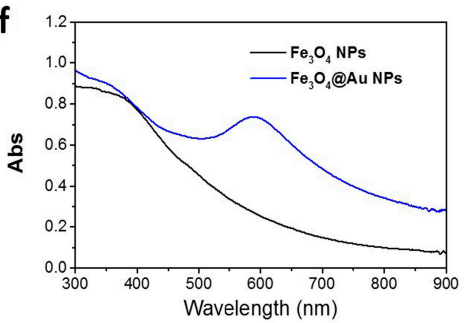

Figure 1. Characterization of $\mathrm{Fe}_{3} \mathrm{O}_{4} @ \mathrm{Au}$ nanoparticles (NPs). (a) TEM images (scale bar: $100 \mathrm{~nm}$ ); (b) Dynamic light scattering analysis of $\mathrm{Fe}_{3} \mathrm{O}_{4} @ \mathrm{Au} \mathrm{NPs}$; (c) Energy dispersive X-ray spectrum of $\mathrm{Fe}_{3} \mathrm{O}_{4}$ NPs; (d) Zeta potential of $\mathrm{Fe}_{3} \mathrm{O}_{4}$ NPs and $\mathrm{Fe}_{3} \mathrm{O}_{4} @ \mathrm{Au}$ NPs; (e) Magnetization curve of $\mathrm{Fe}_{3} \mathrm{O}_{4} @ \mathrm{Au}$ NPs at $300 \mathrm{~K}$; (f) UV-visible-near infrared (NIR) extinction spectrum of $\mathrm{Fe}_{3} \mathrm{O}_{4}$ NPs and $\mathrm{Fe}_{3} \mathrm{O}_{4} @ \mathrm{Au} \mathrm{NPs}$. 


\subsection{Cell Uptake and Cytotoxicity of $\mathrm{Fe}_{3} \mathrm{O}_{4} @ A u$ NPs}

To investigate the therapeutic potential of these NPs against cervical cancer, we first examined the endocytosis of $\mathrm{Fe}_{3} \mathrm{O}_{4} @ \mathrm{Au}$ NPs into HeLa cells using confocal laser scanning microscope (CLSM)and flow cytometry. As shown in Figure 2a, green fluorescence represented fluorescein isothiocyanate (FITC)-labeled $\mathrm{Fe}_{3} \mathrm{O}_{4} @ \mathrm{Au} \mathrm{NPs}$, and red fluorescence indicated lysosomes labeled by LysoTracker-Red. The partial overlay of green fluorescence and red fluorescence after $3 \mathrm{~h}$ incubation exhibited the co-localization of $\mathrm{Fe}_{3} \mathrm{O}_{4} @ \mathrm{Au} \mathrm{NPs}$ and lysosomes, which implied that these $\mathrm{Fe}_{3} \mathrm{O}_{4} @ \mathrm{Au}$ NPs were endocytosed by lysosomes, and some $\mathrm{Fe}_{3} \mathrm{O}_{4} @ \mathrm{Au}$ NPs entered the cytoplasm. More importantly, compared to the absence of a magnetic field, there was an obvious increase in the uptake of $\mathrm{Fe}_{3} \mathrm{O}_{4} @ \mathrm{Au}$ NPs under the magnetic field. A similar endocytic behavior was observed by flow cytometry in Figure $2 b$. Quantitative analysis showed that the mean fluorescence intensity of $\mathrm{Fe}_{3} \mathrm{O}_{4} @ \mathrm{Au}$ NPs under the magnetic field was clearly higher than without the magnetic field. These results demonstrated that $\mathrm{Fe}_{3} \mathrm{O}_{4} @ \mathrm{Au}$ NPs exhibited superior endocytic properties and an external magnetic field could significantly enhance their cellular uptake behavior. To further explore the endocytosis mechanism of the $\mathrm{Fe}_{3} \mathrm{O}_{4} @ \mathrm{Au}$ NPs under the magnetic field, various inhibitors were applied to block the cellular uptake pathways, and flow cytometry was utilized to quantitatively analyze the endocytic behavior. As shown in Figure 2c, the cellular uptake of $\mathrm{Fe}_{3} \mathrm{O}_{4} @ \mathrm{Au}$ NPs dropped obviously in the presence of $\mathrm{NaN}_{3}$, low temperature and chlorpromazine. The results demonstrated that the clathrin-mediated pathway was the main cellular uptake pathway in the energy-dependent endocytosis of $\mathrm{Fe}_{3} \mathrm{O}_{4} @ \mathrm{Au}$ NPs.

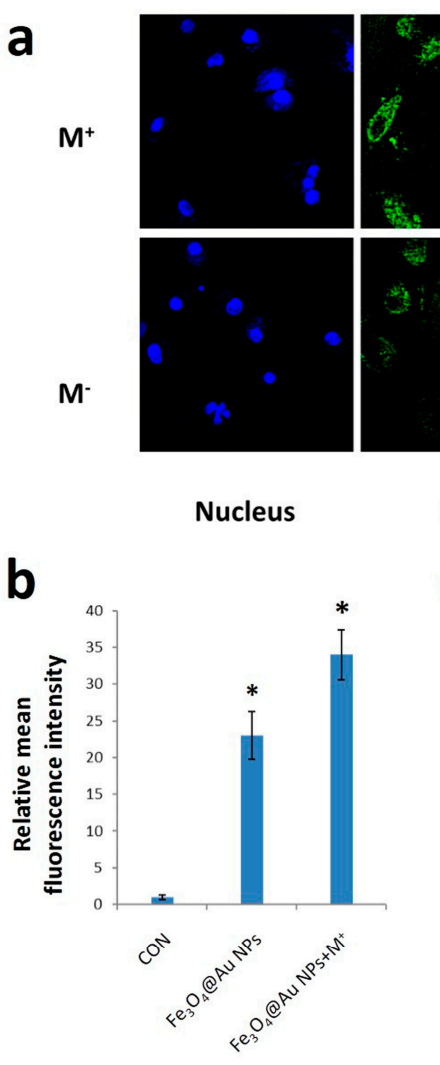

Figure 2. Cell uptake and cytotoxicity of $\mathrm{Fe}_{3} \mathrm{O}_{4} @ \mathrm{Au}$ NPs. endo/lysosomes (red) and $\mathrm{Fe}_{3} \mathrm{O}_{4} @ \mathrm{Au}$ NPs (green) using confocal laser scanning microscopy images, (scale bar: $10 \mu \mathrm{m}$ ); (b) Quantitative analysis of fluorescence intensity of $\mathrm{Fe}_{3} \mathrm{O}_{4} @ \mathrm{Au}$ NPs for $3 \mathrm{~h}$ with or without magnetic field; (c) Endocytic inhibition effect after treatment with various inhibitors. ${ }^{*} p<0.05$ versus NP group. 
To choose a safe dose of $\mathrm{Fe}_{3} \mathrm{O}_{4} @ \mathrm{Au}$ NPs for further biomedical application, we assessed the cytotoxicity of $\mathrm{Fe}_{3} \mathrm{O}_{4} @ \mathrm{Au}$ NPs at various concentrations $(0.78,1.56,3.12,6.25,12.5,25,50$ and $100 \mu \mathrm{g} / \mathrm{mL}$ ) against human cervical cancer HeLa cells with or without the external magnetic field over $24 \mathrm{~h}$ and $48 \mathrm{~h}$ using the sulforhodamine B (SRB) assay. As shown in Figure 3a,b, dose-dependent cytotoxicity was observed for both groups. Furthermore, $\mathrm{Fe}_{3} \mathrm{O}_{4} @ \mathrm{Au}$ NPs displayed a stronger cytotoxicity in the presence of external magnetic fields than outside magnetic fields: the magnetic field force exerted under the bottom side of the cell culture plates may enhance the endocytic ability of $\mathrm{Fe}_{3} \mathrm{O}_{4} @ \mathrm{Au}$ NPs. The cell viability in both groups decreased significantly to $80 \%$ when the concentration was above the $12.5 \mu \mathrm{g} / \mathrm{mL}$. Hence, considering the biosafety of the $\mathrm{Fe}_{3} \mathrm{O}_{4} @ \mathrm{Au} \mathrm{NPs}, 12.5 \mu \mathrm{g} / \mathrm{mL}$ was the optimum dose for further therapy against HeLa cells.
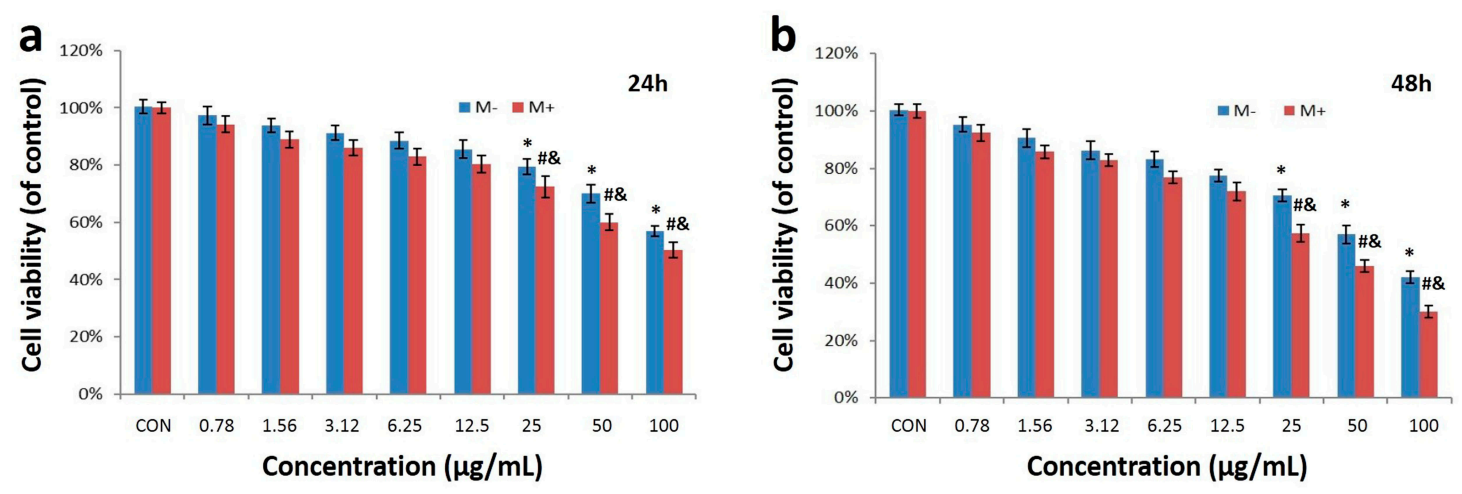

Figure 3. Cytotoxicity of $\mathrm{Fe}_{3} \mathrm{O}_{4} @ \mathrm{Au} \mathrm{NPs}$ to HeLa cells after $24 \mathrm{~h} \mathrm{(a)}$ and $48 \mathrm{~h}(\mathbf{b}) .{ }^{*}, \#, \& p<0.05$ versus control group, \& $p<0.05$ versus non-magnetic treated-group.

\subsection{Photothermal Effect}

To evaluate the light heat conversion capacity of $\mathrm{Fe}_{3} \mathrm{O}_{4} @ \mathrm{Au}$ NPs, the different concentrations $(0-100 \mu \mathrm{g} / \mathrm{mL})$ of NPs in the culture medium were examined under an 808-nm laser irradiation at a power density of $15 \mathrm{~W} / \mathrm{cm}^{2}$. As illustrated in Figure $4 \mathrm{a}$, the temperature of pure water and the blank cell culture medium showed only a $4{ }^{\circ} \mathrm{C}$ increase in $8 \mathrm{~min}$, while the temperature of $\mathrm{Fe}_{3} \mathrm{O}_{4} @ \mathrm{Au}$ NPs solution was obviously increased by $20^{\circ} \mathrm{C}$. The photothermal effects of the NPs were both timeand concentration-dependent. The temperature of $12.5 \mu \mathrm{g} / \mathrm{mL}$ NPs solution reached $43{ }^{\circ} \mathrm{C}$ under irradiation by NIR light after $3 \mathrm{~min}$, which is critical for killing cancer cells. $\mathrm{Fe}_{3} \mathrm{O}_{4} @ \mathrm{Au}$ NPs show excellent photothermal conversion capacity. To further verify the photothermal conversion capacity, we calculated the photothermal conversion efficiency $\eta$ of $\mathrm{Fe}_{3} \mathrm{O}_{4} @ \mathrm{Au} \mathrm{NPs}$ at $808 \mathrm{~nm}$, according to equation [41]:

$$
\eta=\frac{Q_{\mathrm{NPs}}}{I\left(1-10^{-\mathrm{A}}\right)}=\frac{Q-Q_{\mathrm{dis}}}{I\left(1-10^{-\mathrm{A}}\right)}=\frac{h S\left(T_{\max }-T_{0}\right)-Q_{\mathrm{dis}}}{I\left(1-10^{-\mathrm{A}}\right)}
$$

I represents incident laser power, and $\mathrm{A}$ is the absorbance of $\mathrm{Fe}_{3} \mathrm{O}_{4} @ \mathrm{Au}$ NPs at $808 \mathrm{~nm}$. $Q_{\mathrm{NPs}}$ is heat dissipated by electron-phonon relaxation of the plasmons on the $\mathrm{Fe}_{3} \mathrm{O}_{4} @ \mathrm{Au}$ NPs surface under $808 \mathrm{~nm}$ irradiation. $Q$ is the heat conduction away from the system surface by air when the sample cell reaches the equilibrium temperature. $Q_{\text {dis }}$ is the heat dissipation from light absorbed by the container itself, and the value of $Q_{\text {dis }}$ was $5.4 \mathrm{~mW}$ according to the independent measure of a quartz cuvette cell with pure water. $S$ is the surface area of the container, and $h$ is the heat transfer coefficient. $T_{\max }$ is the ultimate temperature after radiation, and $T_{0}$ is the initial temperature. The calculated photothermal conversion efficiency $\eta$ of $\mathrm{Fe}_{3} \mathrm{O}_{4} @ \mathrm{Au}$ NPs was $10.1 \%$. Due to this high photothermal conversion capacity of $\mathrm{Fe}_{3} \mathrm{O}_{4} @ \mathrm{Au}$ NPs, we believe that these NPs can be used as excellent PTT agents.

Encouraged by the strong photothermal conversion capacity, we explored the photothermal effect of $\mathrm{Fe}_{3} \mathrm{O}_{4} @ \mathrm{Au}$ NPs $(12.5 \mu \mathrm{g} / \mathrm{mL})$ on HeLa cell ablation for various irradiation times in the presence or absence of an external magnetic field by the SRB assay. As illustrated in Figure $4 \mathrm{~b}$, only less than 5\% 
of HeLa cells were reduced in the NIR light alone group, even after 5 min of irradiation, compared to the control group. Nevertheless, after incubation with $\mathrm{Fe}_{3} \mathrm{O}_{4} @ \mathrm{Au} \mathrm{NPs}$, the irradiation led to a time-dependent kill effect on HeLa cells. Almost 50\% of the HeLa cells were dead after 5 min NIR irradiation without the magnetic field. Notably, with the aid of an external magnetic field, HeLa cells showed further cell death, reaching almost $60 \%$. The results demonstrated that $\mathrm{Fe}_{3} \mathrm{O}_{4} @ \mathrm{Au}$ NPs had a significant photothermal therapeutic effect on cervical cancer cells and the magnetic field was able to further enhance the photothermal ablation of tumor cells.
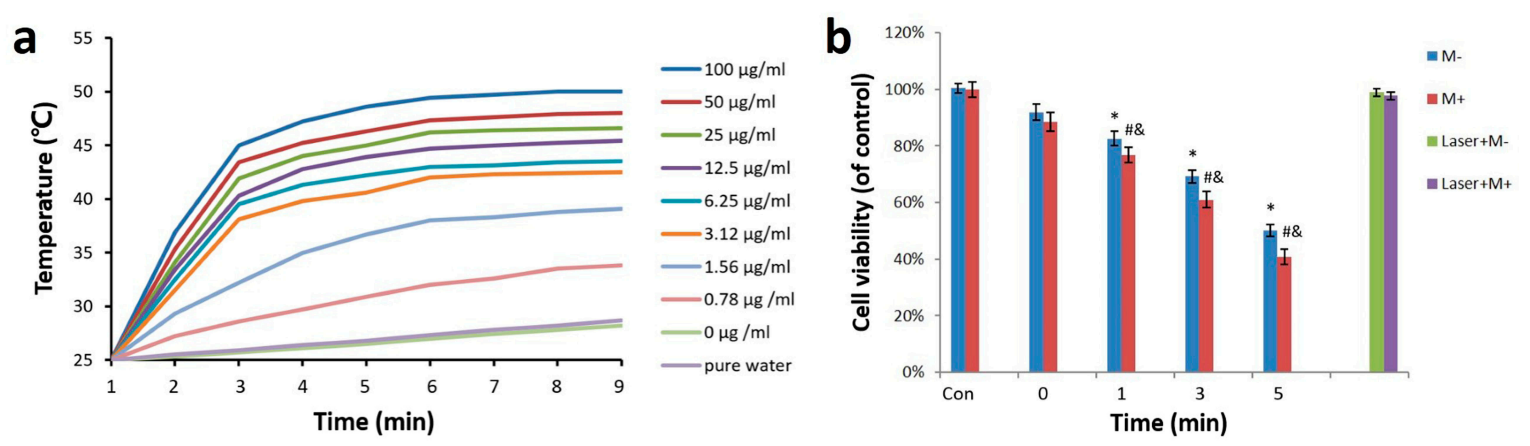

Figure 4. Photothermal conversion capacity of $\mathrm{Fe}_{3} \mathrm{O}_{4} @ \mathrm{Au}$ NPs. (a) Temperature increase at different concentrations of $\mathrm{Fe}_{3} \mathrm{O}_{4} @ \mathrm{Au}$ NPs after different irradiation times; (b) HeLa cell viability after incubation with $\mathrm{Fe}_{3} \mathrm{O}_{4} @ \mathrm{Au}$ NPs for $0,1,3$, and 5 min NIR irradiation. * $\# p<0.05$ versus control group, \& $p<0.05$ versus non-magnetic group.

\subsection{Photothermal-Radiotherapeutic Effect In Vitro}

To determine the potential of $\mathrm{Fe}_{3} \mathrm{O}_{4} @ \mathrm{Au}$ NPs as photothermal agents and radiosensitizers with a synergistic therapeutic effect, the combination of radiotherapy with photothermal therapy was then tested in vitro by the SRB assay. HeLa cells incubated with or without the NPs $(12.5 \mu \mathrm{g} / \mathrm{mL})$ for $12 \mathrm{~h}$ were irradiated by laser alone $\left(15 \mathrm{~W} / \mathrm{cm}^{2}, 10 \mathrm{~min}\right)$, X-ray alone or laser combined with X-ray. As shown in Figure 5, $\mathrm{Fe}_{3} \mathrm{O}_{4} @ \mathrm{Au}$ NPs did not cause substantial cell cytotoxicity without the assistance of NIR or X-ray. After X-ray radiation alone, the cell survival rate was 74.3\%. When HeLa cells incubated with the NPs absorbed the same dose of X-ray radiation alone, the cell survival rate declined remarkably (40.2\%). Interestingly, the same procedure in the presence of a magnetic field resulted in a comparatively high cytotoxicity (the cell survival rate was approximately $30.7 \%$ ). More importantly, radiotherapy and photothermal therapy both inhibited HeLa cell growth, while combined photothermal-radio treatment was markedly superior to either RT alone or PTT alone. In the synergic group, most HeLa cells were damaged (the cell survival rate was $12.7 \%$ ). It is worth noting that the combined treatment in the presence of a magnetic field was found to be more effective in destroying cancer cells than in the absence of a magnetic field.

Fluorescence images of calcein AM (green, live cells) and PI (red, dead cells) co-stained cells was used to further evaluate the efficacy of the combined photothermal-radio treatment. As shown in Figure 6, there was no obvious kill effect on HeLa cells in the NIR-treated group or the NP-treated group. Nevertheless, the treatment with NPs under the laser irradiation resulted in a part of cell death, confirming the effectiveness of PTT using $\mathrm{Fe}_{3} \mathrm{O}_{4} @ \mathrm{Au}$ NPs. Compared with X-ray radiation alone, more red fluorescence was observed when HeLa cells were radiated after incubation with $\mathrm{Fe}_{3} \mathrm{O}_{4} @ \mathrm{Au} \mathrm{NPs}$, which demonstrated that $\mathrm{Fe}_{3} \mathrm{O}_{4} @ \mathrm{Au}$ NPs enhanced the sensibility of HeLa cells to RT. In combining the PTT/RT group, a large number of killed HeLa cells were detected. More importantly, the kill effect was further improved in presence of an extra magnetic field, which was consistent with the cell viability results. Collectively, these results confirmed that $\mathrm{Fe}_{3} \mathrm{O}_{4} @ \mathrm{Au}$ NPs are a promising radiosensitizer with excellent photothermal properties. The combined PTT and RT triggered by $\mathrm{Fe}_{3} \mathrm{O}_{4} @ \mathrm{Au}$ NPs enhanced the inhibitory effects of X-ray irradiation and showed a synergistically higher therapeutic efficacy 
for cervical cancer therapy, and the external magnetic stimulus significantly improved the combined therapeutic effect.

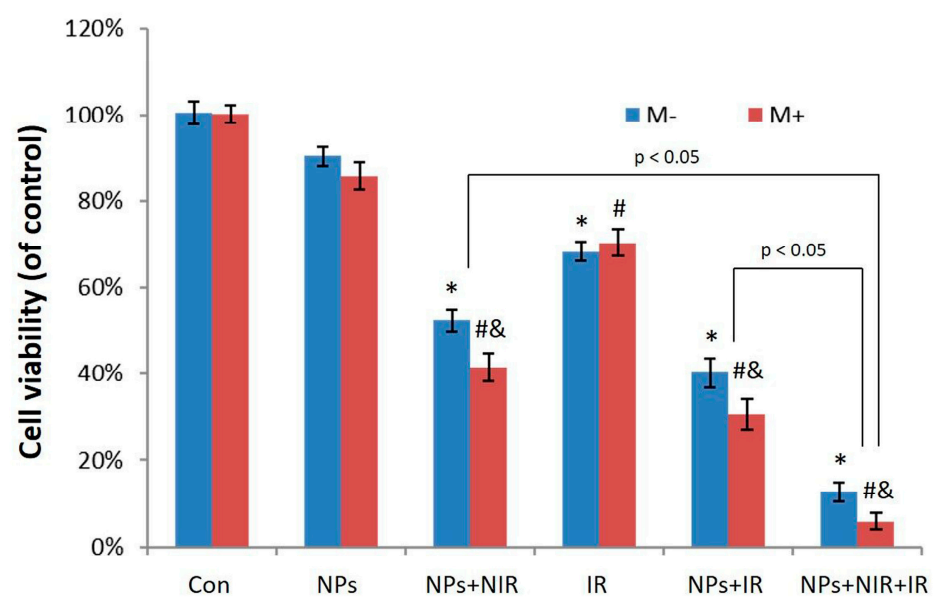

Figure 5. Cell viability of HeLa cells after different treatments. ${ }^{*}, \# p<0.05$ versus control group, $\& p<0.05$ versus non-magnetic group.

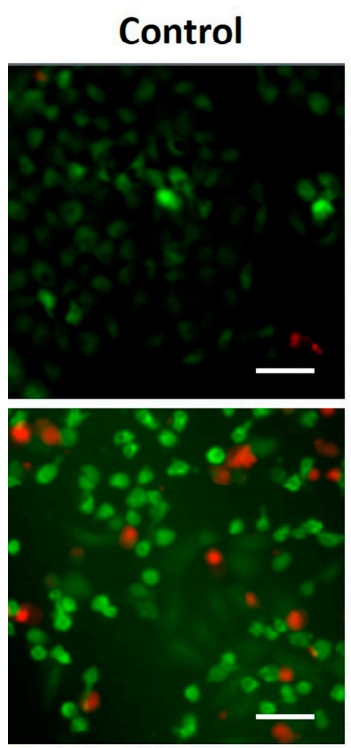

IR
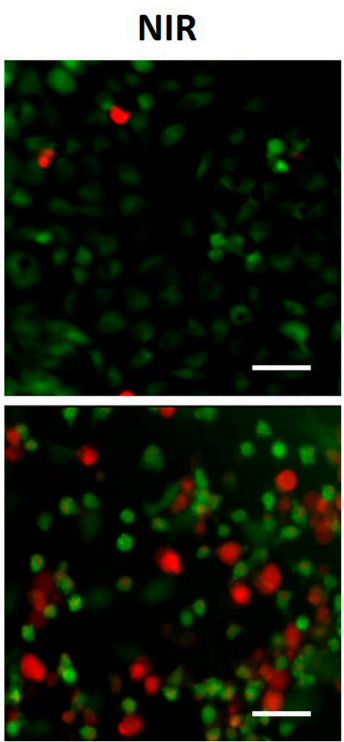

NPs+IR
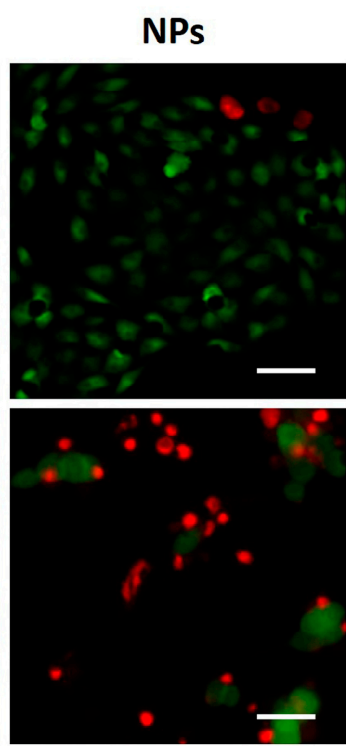

NPs+NIR+IR
NPs+NIR
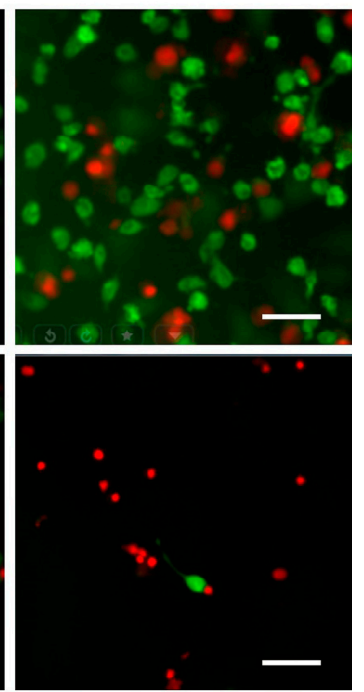

NPs+NIR+IR+M+

Figure 6. Live/Dead assay of HeLa cells after various treatment (scale bar: $50 \mathrm{~mm}$ ).

\section{Materials and Methods}

\subsection{Materials and Reagents}

Iron (III) chloride anhydrous $\left(\mathrm{FeCl}_{3}\right)$, tetrachloroauric acid $\left(\mathrm{HAuCl}_{4} \cdot 3 \mathrm{H}_{2} \mathrm{O}\right)$, fluorescein isothiocyanate (FITC), DAPI and diethylene glycol (DEG) were bought from Sigma (St. Louis, MO, USA). RPMI-1640 medium and fetal bovine serum (FBS) were purchased from Beyotime Institute of Biotechnology (Haimen, Jiangsu, China). Sodium hydroxide and ethyl alcohol were obtained from Beijing Chemical Reagnet. All the reagents and materials could be bought and were not further purified before use. 


\subsection{Preparation of $\mathrm{Fe}_{3} \mathrm{O}_{4}$ Nanoparticles and $\mathrm{Fe}_{3} \mathrm{O}_{4} @ A$ A Nanoparticles}

$\mathrm{Fe}_{3} \mathrm{O}_{4}$ NPs were synthesized via a high-temperature hydrolysis process. First, $2.0 \mathrm{~g}$ sodium hydroxide was added to $20 \mathrm{~mL} \mathrm{DEG}$ at $120{ }^{\circ} \mathrm{C}$ for $1 \mathrm{~h}$. Then, $0.8 \mathrm{mmol} \mathrm{FeCl}_{3}$ and $8 \mathrm{mmol} \mathrm{PAA}$ were added to $34 \mathrm{~mL}$ DEG and mixed in a three-necked flask with stirring. After $30 \mathrm{~min}$, the mixture was heated to $265{ }^{\circ} \mathrm{C}$ under nitrogen protection. Then, $3.8 \mathrm{~mL}$ of DEG solution of $\mathrm{NaOH}$ was rapidly injected into the mixture and reacted for $1 \mathrm{~h}$. Spherical $\mathrm{Fe}_{3} \mathrm{O}_{4}$ nanoparticles were obtained after washing by centrifugation.

$\mathrm{Fe}_{3} \mathrm{O}_{4} @ \mathrm{Au}$ NPs were prepared using the reduction of gold iron with a hydroxylamine-coated $\mathrm{Fe}_{3} \mathrm{O}_{4}$ core. First, $1 \mathrm{~mL}$ of $\mathrm{Fe}_{3} \mathrm{O}_{4}$ solution $(8.6 \mathrm{mg} / \mathrm{mL})$ was injected into $0.1 \mathrm{~mol} / \mathrm{L} \mathrm{HAuCl}_{4} \cdot 4 \mathrm{H}_{2} \mathrm{O}$ solution and stirred for $3 \mathrm{~h}$. Then, $0.8 \mathrm{~mL}$ of ammonium hydroxide was added to the system. The mixture was heated to $40{ }^{\circ} \mathrm{C}$ for $1 \mathrm{~h}$. The core-shell $\mathrm{Fe}_{3} \mathrm{O}_{4} @ \mathrm{Au}$ nanoparticles were formed. In addition, FITC-labeled $\mathrm{Fe}_{3} \mathrm{O}_{4} @ \mathrm{Au}$ NPs were synthesized using the same protocol, except that FITC $(0.5 \mathrm{mg})$ was added to a solution of $0.1 \mathrm{~mol} / \mathrm{L} \mathrm{HAuCl}_{4} \cdot 4 \mathrm{H}_{2} \mathrm{O}$ before being mixed with $\mathrm{Fe}_{3} \mathrm{O}_{4}$ nanoparticles in the dark.

\subsection{Characterization of Core-Shell $\mathrm{Fe}_{3} \mathrm{O}_{4} @ A u$ NPs}

The morphology and shape of core-shell $\mathrm{Fe}_{3} \mathrm{O}_{4} @ \mathrm{Au}$ nanoparticles were characterized by TEM images (Suzhou University, Suzhou City, China)) with 200 kV. The size of $\mathrm{Fe}_{3} \mathrm{O}_{4} @ \mathrm{Au}$ NPs was obtained on a ZetaPALS + BI-90Plus system. Magnetic properties were measured by VSM at $300 \mathrm{~K}$. The photothermal effect of $\mathrm{Fe}_{3} \mathrm{O}_{4} @ \mathrm{Au}$ NPs was examined by measuring the temperature of RPMI-1640 solution of $\mathrm{Fe}_{3} \mathrm{O}_{4} @ \mathrm{Au} \mathrm{NPs}$ at different concentrations (0, 0.78, 1.56, 3.12, 6.25, 12.5, 25, 50 and $100 \mu \mathrm{g} / \mathrm{mL})$ under NIR laser irradiation $\left(808 \mathrm{~nm}, 15 \mathrm{~W} / \mathrm{cm}^{2}\right)$ every $10 \mathrm{~s}$.

\subsection{Cell Uptake Test}

HeLa cells were cultured on a clean 24 -well plate at $2 \times 10^{4}$ cells per well and maintained at $37{ }^{\circ} \mathrm{C}$ in RPMI-1640 medium with $10 \%(v / v)$ fetal bovine serum for $24 \mathrm{~h}$. Then, FITC-labeled $\mathrm{Fe}_{3} \mathrm{O}_{4} @ \mathrm{Au}$ NPs were co-cultured with HeLa cells for $3 \mathrm{~h}$ with or without cylindrical NdFeB permanent magnets (surface magnetic field of $0.2 \mathrm{~T}$ ) placed under the 24 -well plate. Then, DAPI $(5 \mathrm{mg} / \mathrm{mL}$ ) was used to stain the nuclei, and the cells were washed twice with PBS. A confocal laser scanning microscope (Olympus FV1000, C.L., Suzhou University, Suzhou, China) was used to observe the cell uptake of $\mathrm{Fe}_{3} \mathrm{O}_{4} @ \mathrm{Au}$ NPs. Flow cytometry (C.L., Suzhou University, Suzhou, China) was utilized to quantitate the cell uptake of $\mathrm{Fe}_{3} \mathrm{O}_{4} @ \mathrm{Au}$ NPs. Briefly, HeLa cells were cultured on a clean 24-well plate and co-cultured with FITC-labeled $\mathrm{Fe}_{3} \mathrm{O}_{4} @ \mathrm{Au}$ for $24 \mathrm{~h}$ with or without a magnetic field. Then, the supernatant liquid was removed, and the cells were washed with PBS. The HeLa cells were resuspended through trypsinization, and the fluorescence content was examined by flow cytometer.

The endocytic mechanism was analyzed by treatment with various inhibitors to block the uptake pathway. For this purpose, $3.0 \mathrm{mg} / \mathrm{mL} \mathrm{NaN}_{3}$ was used to deplete ATP, $20 \mu \mathrm{g} / \mathrm{mL}$ chlorpromazine was used to inhibit the clathrin-mediated pathway, $10 \mu \mathrm{g} / \mathrm{mL}$ simvastatin was used to inhibit the caveolae/lipid rafts pathway, $5 \mu \mathrm{g} / \mathrm{mL}$ mycostatin was used to inhibit the caveolae-mediated pathway, and $10 \mu \mathrm{g} / \mathrm{mL}$ of amiloride was used to inhibit the macropinocytosis pathway. The energy-dependent endocytosis was hindered by incubation at $4{ }^{\circ} \mathrm{C}$. After incubation with the inhibitors for $30 \mathrm{~min}$, the supernatant liquid with the inhibitors was removed, and the cells were washed with PBS and trypsinized. The flow cytometer was utilized to quantify the cell uptake of $\mathrm{Fe}_{3} \mathrm{O}_{4} @ \mathrm{Au}$.

\subsection{In Vitro Cytotoxicity Assay}

The inhibitory effects of each group on HeLa cells were evaluated through sulforhodamine B (SRB) assay. Briefly, $5 \times 10^{4}$ cells were cultured on clean 96-well plates under standard culture conditions for $24 \mathrm{~h}$. Then, the cells were treated with $\mathrm{Fe}_{3} \mathrm{O}_{4} @ \mathrm{Au}$ NPs at various concentrations with or without NIR laser $\left(808 \mathrm{~nm}, 15 \mathrm{~W} / \mathrm{cm}^{2}\right)$ and X-ray irradiation ( $5 \mathrm{~Gy}, 5 \mathrm{~min}$ ) under or outside the magnetic field for 
$24 \mathrm{~h}$ and $48 \mathrm{~h}$. Then, $0.4 \%(w / v)$ of sulforhodamine B was added to bind with the live cells protein. After washing by acetic acid and dissolution by Tris-base, the optical densityat $570 \mathrm{~nm}$ was examined, and the cell viability was calculated.

\subsection{Statistical Analysis}

All data were from three separate tests; experimental data were expressed as the mean $\pm \mathrm{SD}$. The data was analyzed by Student's test and $p<0.05$ indicated a difference in a statistically significant field.

\section{Conclusions}

In summary, we designed uniform core-shell type $\mathrm{Fe}_{3} \mathrm{O}_{4} @ \mathrm{Au}$ NPs with a superb near-infrared absorption and excellent superparamagnetic property. The as-synthesized NPs exhibited low cytotoxicity, and the application of a magnetic field enhanced their endocytic ability. As potential photo-absorbing agents, $\mathrm{Fe}_{3} \mathrm{O}_{4} @ \mathrm{Au}$ NPs show an excellent photothermal therapeutic effect against HeLa cells. When combined with X-ray radiation, the NPs could generate a synergistically radio-photothermal therapeutic effect. More importantly, these novel multifunctional NPs exhibited enhanced therapeutic efficacy with the aid of a magnetic field. This work highlights the potential of $\mathrm{Fe}_{3} \mathrm{O}_{4} @ \mathrm{Au} \mathrm{NPs}$ as a novel multifunctional nanoplatform for cervical cancer radio-photothermal treatment.

Acknowledgments: This work was supported by the National Natural Science Foundation of China (Grand Nos. 61535010 and 81601609), Key Research Program of the Chinese Academy of Sciences (No. KFZD-SW-204), the Natural Science Foundation of Jiangsu Province (No. BE2015601), the Science and Technology Department of Suzhou City (Nos. SS201539 and ZXY201434) and Suzhou Key Medical Center (No. Szzx201506).

Author Contributions: For this research articles, Z.C. and W.D. conceived and designed the experiments; R.H. synthesized the nanoparticles and participated in all experiments; M.Z. analyzed the data; J.W. and C.L. performed TEM imaging, dynamic light scattering analysis and UV-visible-NIR absorption spectra experiments; D.S. and D.Y. performed the cell experiments; M.G. and L.L. analyzed the data.

Conflicts of Interest: The authors declare no conflict of interest.

\section{References}

1. Maluccio, M.; Covey, A. Recent progress in understanding, diagnosing, and treating hepatocellular carcinoma. Cancer J. Clin. 2012, 62, 394-399. [CrossRef] [PubMed]

2. Bosch, F.X.; De Sanjosé, S. Human papillomavirus and cervical cancer-burden and assessment of causality. J. Natl. Cancer Inst. Monogr. 2002, 31, 3-13. [CrossRef]

3. Siegel, R.; Naishadham, D.; Jemal, A. Cancer statistics, 2012. Cancer J. Clin. 2012, 62, 10-29. [CrossRef] [PubMed]

4. Monk, B.J.; Tewari, K.S.; Koh, W.J. Multimodality therapy for locally advanced cervical carcinoma: State of the art and future directions. J. Clin. Oncol. 2007, 25, 2952-2965. [CrossRef] [PubMed]

5. Rose, P. Chemoradiotherapy for cervical cancer. Eur. J. Cancer 2002, 38, 270-278. [CrossRef]

6. Small, W.; Winter, K.; Levenback, C. Extended-field irradiation and intracavitary brachytherapy combined with cisplatin chemotherapy for cervical cancer with positive para-aortic or high common iliac lymph nodes: Results of ARM 1 of RTOG 0116. Int. J. Radiat. Oncol. Biol. Phys. 2007, 68, 1081-1087. [CrossRef] [PubMed]

7. RYU, H.S.; Kang, S.; Kim, K.T.; Chang, K.H.; Kim, J.; Kim, J.H. Efficacy of different types of treatment in FIGO stage IB2 cervical cancer in Korea: Results of a multicenter retrospective Korean study (KGOG-1005). Int. J. Gynecol. Cancer 2007, 17, 132-136. [CrossRef] [PubMed]

8. Ho, C.M.; Chien, T.Y.; Huang, S.H.; Wu, C.J.; Shih, B.Y.; Chang, S.C. Multivariate analysis of the prognostic factors and outcomes in early cervical cancer patients undergoing radical hysterectomy. Gynecol. Oncol. 2004, 93, 458-464. [CrossRef] [PubMed]

9. Takeuchi, S.; Dobashi, K.; Fujimoto, S. A late phase II study of CPT-11 on uterine cervical cancer and ovarian cancer. Research Groups of CPT-11 in Gynecologic Cancers. Gan Kagaku Ryoho 1991, 18, 1681-1689. 
10. Takeda, N.; Sakuragi, N.; Takeda, M. Multivariate analysis of histopathologic prognostic factors for invasive cervical cancer treated with radical hysterectomy and systematic retroperitoneal lymphadenectomy. Acta Obstet. Gynecol. Scand. 2002, 81, 1144-1151. [CrossRef] [PubMed]

11. Ungár, L.; Pálfalvi, L.; Hogg, R. Abdominal radical trachelectomy: A fertility-preserving option for women with early cervical cancer. BJOG 2005, 112, 366-369. [CrossRef] [PubMed]

12. Chopra, R.R.; Bogart, J.A. Radiation Therapy-Related Toxicity (including Pneumonitis and Fibrosis). Clin. Oncol. 2010, 24, 625-642. [CrossRef] [PubMed]

13. Greimel, E.R.; Winter, R.; Kapp, K.S.; Haas, J. Quality of life and sexual functioning after cervical cancer treatment: A long-term follow-up study. Psycho-Oncology 2009, 18, 476-482. [CrossRef] [PubMed]

14. Wang, C. Prehydrated Electron and Its Role in Ionizing Radiation Induced DNA Damage and Molecular Mechanisms of Action of Halogenated Sensitizers for Radiotherapy of Cancer; UWSpace: Waterloo, ON, Canada, 2012.

15. Cole, J.R.; Mirin, N.A.; Knight, M.W.; Goodrich, G.P.; Halas, N.J. Photothermal efficiencies of nanoshells and nanorods for clinical therapeutic applications. J. Phys. Chem. C 2009, 113, 12090-12094. [CrossRef]

16. Huang, X.; El-Sayed, I.H.; Qian, W.; El-Sayed, M.A. Cancer cell imaging and photothermal therapy in the near-infrared region by using gold nanorods. J. Am. Chem. Soc. 2006, 128, 2115-2120. [CrossRef] [PubMed]

17. Kunjachan, S.; Detappe, A.; Kumar, R. Nanoparticle mediated tumor vascular disruption: A novel strategy in radiation therapy. Nano Lett. 2015, 15, 7488-7496. [CrossRef] [PubMed]

18. Hainfeld, J.F.; Lin, L.; Slatkin, D.N.; Dilmanian, F.A.; Vadas, T.M.; Smilowitz, H.M. Gold nanoparticle hyperthermia reduces radiotherapy dose. Nanomedicine 2014, 10, 1609-1617. [CrossRef] [PubMed]

19. Diagaradjane, P.; Shetty, A.; Wang, J.C. Modulation of in vivo tumor radiation response via gold nanoshell-mediated vascular-focused hyperthermia: Characterizing an integrated antihypoxic and localized vascular disrupting targeting strategy. Nano Lett. 2008, 8, 1492-1500. [CrossRef] [PubMed]

20. Wang, Z.; Wang, Y.; Chang, Z. Berberine-loaded Janus Nanocarriers for Magnetic Field-Enhanced Therapy against Hepatocellular Carcinoma. Chem. Biol. Drug Des. 2016, 89, 464-469. [CrossRef] [PubMed]

21. Shao, D.; Li, J.; Zheng, X. Janus "nano-bullets" for Magnetic Targeting Liver Cancer Chemotherapy. Biomaterials 2016, 100, 118-133. [CrossRef] [PubMed]

22. Shao, D.; Wang, Z.; Dong, W.F. Facile Synthesis of Core-shell Magnetic Mesoporous Silica Nanoparticles for pH-sensitive Anticancer Drug Delivery. Chem. Biol. Drug Des. 2015, 86, 1548-1553. [CrossRef] [PubMed]

23. Wang, Z.; Wang, Y.; Lu, M. Janus Au-mesoporous silica nanocarriers for chemo-photothermal treatment of liver cancer cells. RSC Adv. 2016, 6, 44498-44505. [CrossRef]

24. Mieszawska, A.J.; Mulder, W.J.; Fayad, Z.A.; Cormode, D.P. Multifunctional gold nanoparticles for diagnosis and therapy of disease. Mol. Pharm. 2013, 10, 831-847. [CrossRef] [PubMed]

25. Wang, Y.S.; Shao, D.; Zhang, L. Gold nanorods-silica Janus nanoparticles for theranostics. Appl. Phys. Lett. 2015, 106, 173705. [CrossRef]

26. Hainfeld, J.F.; Dilmanian, F.A.; Slatkin, D.N.; Smilowitz, H.M. Radiotherapy enhancement with gold nanoparticles. J. Pharm. Pharmacol. 2008, 60, 977-985. [CrossRef] [PubMed]

27. Lucarini, M.; Franchi, P.; Pedulli, G.F.; Pengo, P.; Scrimin, P.; Pasquato, L. EPR study of dialkyl nitroxides as probes to investigate the exchange of solutes between the ligand shell of monolayers of protected gold nanoparticles and aqueous solutions. J. Am. Chem. Soc. 2004, 126, 9326-9329. [CrossRef] [PubMed]

28. Torchilin, V. Tumor delivery of macromolecular drugs based on the EPR effect. Adv. Drug Deliv. Rev. 2011, 63, 131-135. [CrossRef] [PubMed]

29. Maeda, H.; Wu, J.; Sawa, T.; Matsumura, Y.; Hori, K. Tumor vascular permeability and the EPR effect in macromolecular therapeutics: A review. J. Control. Release 2000, 65, 271-284. [CrossRef]

30. Dobson, J. Magnetic nanoparticles for drug delivery. Drug Dev. Res. 2006, 67, 55-60. [CrossRef]

31. Peng, X.H.; Qian, X.; Mao, H. Targeted magnetic iron oxide nanoparticles for tumor imaging and therapy. Int. J. Nanomed. 2008, 3, 311-321.

32. Chomoucka, J.; Drbohlavova, J.; Huska, D.; Adam, V.; Kizek, R.; Hubalek, J. Magnetic nanoparticles and targeted drug delivering. Pharmacol. Res. 2010, 62, 144-149. [CrossRef] [PubMed]

33. Yang, H.; Zhuang, Y.; Hu, H. Silica-coated manganese oxide nanoparticles as a platform for targeted magnetic resonance and fluorescence imaging of cancer cells. Adv. Funct. Mater. 2010, 20, 1733-1741. [CrossRef]

34. Veiseh, O.; Gunn, J.W.; Zhang, M. Design and fabrication of magnetic nanoparticles for targeted drug delivery and imaging. Adv. Drug Deliv. Rev. 2010, 62, 284-304. [CrossRef] [PubMed] 
35. Wang, L.; Park, H.-Y.; Stephanie, I.; Lim, I.; Schadt, M.J.; Mott, D.; Luo, J.; Wang, X.; Zhong, C.-J. Core@shell nanomaterials: Gold-coated magnetic oxide nanoparticles. J. Mater. Chem. 2008, 18, 2629-2635. [CrossRef]

36. Ahmadi, A.; Shirazi, H.; Pourbagher, N.; Akbarzadeh, A.; Omidfar, K. An electrochemical immunosensor for digoxin using core-shell gold coated magnetic nanoparticles as labels. Mol. Boil. Rep. 2014, 41, 1659-1668. [CrossRef] [PubMed]

37. Tamer, U.; Gündoğdu, Y.; Boyacı, İ.H.; Pekmez, K. Synthesis of magnetic core-shell $\mathrm{Fe}_{3} \mathrm{O}_{4}-\mathrm{Au}$ nanoparticle for biomolecule immobilization and detection. J. Nanopart. Res. 2010, 12, 1187-1196. [CrossRef]

38. Park, H.-Y.; Schadt, M.J.; Wang, L.; Lim, I.-I.S.; Njoki, P.N.; Kim, S.H.; Jang, M.-Y.; Luo, J.; Zhong, C.-J. Fabrication of Magnetic Core@Shell Fe Oxide@Au Nanoparticles for Interfacial Bioactivity and Bio-separation. Langmuir 2007, 23, 9050-9056. [CrossRef] [PubMed]

39. Robinson, I.; Tung, L.D.; Maenosono, S.; Wälti, C.; Thanh, N.T. Synthesis of core-shell gold coated magnetic nanoparticles and their interaction with thiolated DNA. Nanoscale 2010, 2, 2624-2630. [CrossRef] [PubMed]

40. Tian, Q.; Jiang, F.; Zou, R.; Liu, Q.; Chen, Z.; Zhu, M.; Yang, S.; Wang, J.; Wang, J.; Hu, J. Hydrophilic Cu, $\mathrm{S}_{5}$ Nanocrystals: A Photothermal Agent with a 25.7\% Heat Conversion Efficiency for Photothermal Ablation of Cancer Cells In Vivo. ACS Nano 2011, 5, 9761-9771. [CrossRef] [PubMed]

41. Roper, D.K.; Ahn, W.; Hoepfner, M. Microscale heat transfer transduced by surface plasmon resonant gold nanoparticles. J. Phys. Chem. C Nanomater. Interfaces 2007, 111, 3636-3641. [CrossRef] [PubMed]

(c) 2017 by the authors. Licensee MDPI, Basel, Switzerland. This article is an open access article distributed under the terms and conditions of the Creative Commons Attribution (CC BY) license (http:// creativecommons.org/licenses/by/4.0/). 